\title{
Land Equation Value of Secondary Plant Polyculture System in High Land and Low Land Farmers
}

${ }^{1}$ Yusmiati Sabang, ${ }^{2}$ Nurariaty Agus, ${ }^{3}$ Sitti Bulkis, ${ }^{4}$ Muhammad Arsyad

${ }^{*}$ Doctoral Student, Hasanuddin University/Social Economic Agriculture, Makassar, South Sulawesi, Indonesia

${ }^{2}$ Professor Department of Plant Pests and Diseases, Hasanuddin University/Faculty of Agriculture, Makassar, South Sulawesi, Indonesia

${ }^{3}$ Professor Department of Socio-economics of Agriculture, Hasanuddin University/Faculty of Agriculture, Makassar, South Sulawesi, Indonesia

${ }^{4}$ Lecturer Department of Socio-economics of Agriculture, Hasanuddin University/Faculty of Agriculture, Makassar, South Sulawesi, Indonesia

\begin{abstract}
Cropping pattern systems can affect the level of productivity of land, land use by applying the right cropping system is not only able to increase production but can improve the efficiency of use of space and time. The polyculture (intercropping) system of secondary crops is a potential model to be developed. The needs of secondary crops such as corn and soybeans in Indonesia have increased from year to year, but their production has not been able to meet market demand. This is due to reduced agricultural land for cultivation. The purpose of this study was to analyze the efficiency of land use of polyculture systems of secondary crops carried out by highland and lowland farmers. This research was carried out on farmland which carried out the cropping pattern of the polyculture system of secondary crops which was 60 days old. Quantitative descriptive research method through surveys using questionnaires. The results showed that the highest value of land equality (NKL) occurred in corn-peanuts. The soil was 5.7 and the lowest was polyculture systems of green beans (1.5). This study suggests that farmers in both regions, a highland and lowland farmers, are given socialization and training on maximum land use so that they can increase knowledge and increase farmer household income.
\end{abstract}

Keywords: NKL, Polyculture System, Crops, Highland, Lowland

\section{INTRODUCTION}

Crops are food crops which are a source of carbohydrates and proteins in addition to rice. Crops commodities include corn, soybeans, peanuts, and cassava. Secondary crops is very potential to be developed to support food security to reduce dependence on rice. In other words, secondary crops are diversification of non-rice food sources. About 7.5 million households or around 30 million make secondary crops as a source of income (Damardjati, 2007).

Crops include corn, soybeans, peanuts, green beans, cassava, and sweet potatoes. Most of the secondary crops are not native to Indonesia, but they have adapted and been cultivated in Indonesia. Crops are a potential plant to be developed because the results can be used as a source of carbohydrates, sources of vegetable protein, and basic ingredients of various industries. The problem faced today is the limited 
productive agricultural land. One effort to optimize the existing agricultural land is the polyculture system. The polyculture system is a system of managing agricultural land by combining intensification and diversification of plants. Corn is the most productive cereal plant in the world, while green beans are legumes that are quite important in Indonesia and occupy the third place after soybeans and peanuts (Warsana, 2009).

The highland and lowland farming communities in Bone Regency have long been cultivating in a polyculture system but not continuously, planting is done only based on knowledge from generation to generation and only for personal consumption. So that farmers do not pay attention in terms of spacing, types of plants that can be intercropped and the frequency of proper planting. Differences that occur between highland and lowland farmers, that highland farmers plant more types of intercropped crops compared to lowland farmers, so that highland farmers are able to utilize the land as much as possible to increase crop production and land productivity. Whereas lowland farmers only plant 2 (two) types of crops on their cropland which are known to have the land area of each lowland farmer only in the range of $0.25-1$ ha, so that the land use is not much, many lowland farmers who plant the system monoculture.

In general, polyculture systems are more profitable than monoculture systems because the productivity of the land becomes high, the types of commodities produced vary, saving the use of production facilities and the risk of failure can be minimized (Beets, 1992). Besides that the polyculture system can also reduce erosion, even this method successfully maintains soil fertility (Ginting and Yusuf, 1993). The agronomic advantages of implementing a polyculture system can be evaluated by calculating the land equality ratio. The ratio of land equality $>1$ means profitable (Beets, 1992). Land productivity in the polyculture system is calculated based on the land equality ratio (NKL). Plants that are mutually beneficial, the value of NKL is more than one. If one plant species is depressed (not mutually beneficial) then the value of the NKL is less than one. The production of polyculture (intercropping) between corn and green beans shows that NKL 1.50 means that the efficiency of land use is 50\% (Anonim, 2011). Advantages in land use in intercropping systems are growth resources such as light, water, nutrients more efficiently in each of which are competitively intercropped such as the level of canopy development, width, and height of the canopy, adaptation of radiation conditions, and depth of roots (Kipkemori et al, 1997)

This study aims to analyze the efficiency of land use of the polyculture system of secondary crops carried out by highland and lowland farmers.

\section{METHODS}

This research was conducted from January to May 2018 in Selli Village (highland) and Talungeng Village (lowland) Bone Regency. The polyculture system carried out by farmers in the study locations was intercropping of soybean-corn, corn-peanuts, soybean-green beans and corn monoculture, soybean monoculture, peanut monoculture, and green beans monoculture. Sampling was carried out on secondary crops plantations belonging to farmers who planted polyculture systems and monoculture systems that were 60 days old (days after planting).

\section{DATA ANALYSIS}

The data obtained is then calculated by analysis of land use efficiency or NKL. Efficiency analysis of land use was carried out to analyze the land use of the polyculture system of corn-soybean, corn-k land, soybean. The value of the NKL can determine the productivity of land planted by polyculture and monoculture systems. If the results of the analysis 
show that the NKL value is greater than $1(>1)$, this indicates that the polyculture system is more productive than the monoculture system. To calculate the increase in land production produced in this study, the following formula is used:

Where :

$$
\mathrm{NKL}=\frac{Y a b}{Y b a}+\frac{Y a a}{Y b b}
$$

$\mathrm{Yab}=$ Results of the plants $\mathrm{A}$ that is planted in intercropping

Yaa $=$ Results of plants $B$ that is planted intercropping

$\mathrm{Yba}=$ Results of the plants $\mathrm{A}$ that is planted in monoculture

$\mathrm{Ybb}=$ Results of plants $\mathrm{B}$ that is planted in monoculture

\section{RESULTS AND DISCUSSION}

\section{Value of Land Equity (NKL)}

Polyculture system is a crop cultivation system that can increase land production. The agricultural business system aims to get more than one crop yield of the type or several types of plants on the same plot of land in one year. This choice is taken to reduce the level of risk of production failure, absorb more evenly labor throughout the year, increase land productivity, and make more efficient use of energy or sunlight and in water use. Land equality ratio (NKL) is one method of calculating the productivity of land planted by two or more types of plants planted in a polyculture system. NKL is a comparison of the number of plant ratios planted in polyculture with plants in monoculture on the same management, if NKL> 1 means profitable (Kidane et al., 1990; Kipkemori et al., 1997; Li et al. 2001, Suwarto et al. 2005). The following is a table of the average value of the calculation of land equality ratio (NKL):
Table 1. NKL of Corn-Soybean, Corn-Peanuts, Soybean-Green Beans Production in Polyculture Systems in Sellli Village (Plateau) and Talungeng Village (Lowland)

\begin{tabular}{|c|c|c|c|c|c|c|}
\hline Area & $\begin{array}{c}\text { Polycult } \\
\text { ure }\end{array}$ & $\begin{array}{l}\text { Cor } \\
\mathrm{n}\end{array}$ & $\begin{array}{l}\text { Soy } \\
\text { bean }\end{array}$ & $\begin{array}{r}\text { Pean } \\
\text { uts }\end{array}$ & $\begin{array}{c}\text { Gree } \\
\mathrm{n} \\
\text { beans }\end{array}$ & NKL \\
\hline \multirow{3}{*}{$\begin{array}{l}\text { High } \\
\text { land }\end{array}$} & $\begin{array}{c}\text { Corn- } \\
\text { Soybean }\end{array}$ & 42 & 27 & - & - & 3,2 \\
\hline & $\begin{array}{c}\text { Corn- } \\
\text { Peanuts }\end{array}$ & 25,3 & - & 15,8 & & 5,7 \\
\hline & $\begin{array}{c}\text { Soybean } \\
\text {-Green } \\
\text { Beans }\end{array}$ & - & 11,85 & - & 7,45 & 1,5 \\
\hline $\begin{array}{l}\text { Low } \\
\text { land }\end{array}$ & $\begin{array}{c}\text { Corn- } \\
\text { Soybean }\end{array}$ & 39 & 24,7 & - & - & 2,0 \\
\hline
\end{tabular}

Based on the calculation of the land equality ratio (NKL), it shows that all treatments on the polyculture system have more than 1 NKL value, both in the highlands and in the lowlands. This means that with the polyculture system between corn-soybeans, cornpeanuts and soybeans-green beans can increase land productivity, even the highest NKL value is in the corn-peanuts polyculture system. Soil which is $\mathbf{5 . 7}$ is in the highlands region. Guritno (2011) states, the value of NKL> 1 indicates that the monoculture system requires more land than the polyculture system, meaning that the application of a polyculture system increases land use so that it is more efficient than a monoculture system. The high value of NKL in the corn-peanuts. Soil polyculture system is due to the two plants being able to adapt to the environment widely and relatively have the same growing conditions. Corn is a plant that is somewhat resistant to drought and is efficient in the use of light, while peanuts is a plant that is resistant to shade and roots capable of binding nitrogen (N2) from the air through symbiosis with Rhizobium bacteria (Adisarwanto, 2003). The corn polyculture system with beans increases the efficiency of land resource 
utilization, increases harvest volume and frequency compared to the monoculture planting system (Sucipto 2009, Syaifuddin et al. 2010 and Sabaruddin et al. 2011). And also the potential results in legume/non-legume polyculture (intercropping) systems depend on growth patterns, nutrient requirements and suitability of the plants involved. The ability of polyculture planting patterns (intercropping) is able to improve soil fertility through Nitrogen fixation in legume plants compared to monoculture (Gomes, 1983; Lithourgidis et al., 2011).

The selection of each variety of crops that are appropriate according to the condition of the land and the area to be used as intercropping area greatly determines the size of crop productivity. The availability of water sources, especially at the beginning of growth, greatly determines the subsequent development of plants. Like the generative growth phase (filling pods) at the soybeans is a very critical phase in determining production. Lack of water causes the filling of pods not to be optimal so that the production of soybeans is not optimal (Ahmad et al., 2013).

The difference in the NKL value of the polyculture system of highland and lowland crops is strongly influenced by the behavior of farmers in managing their plantations with the potential of different land areas of each farmer. In the highlands, which are at an altitude of around 500 asl, which can allow planting of secondary crops, with land potentials ranging from 0.25-2.25 ha, more highland farmers do polyculture with the conditions of rainfed lowland so that the planting of secondary crops carried out during the dry season when the availability of water resources is very scarce and limited. Whereas in the lowlands with the potential of land only ranging from $0.25-1.0$ ha and the NKL value is more than 1, farmers should implement a polyculture system continuously because it can increase land productivity, but this is different from findings in the field where more farmers do monoculture system is caused by conflicts that occur within the peasant community that are related to the availability of water sources or irrigation, and it is not uncommon for farmers to consider that polyculture system maintenance costs are more expensive because they have to treat more than one type of crop, so farmers prefer monoculture system.

\section{CONCLUSION}

The highest land equality ratio (NKL) of farmers is in the highland communities on the corn-peanut polyculture system (5.7) when compared to the lowland community in the corn-soybean polyculture system (2.0). This is because highland communities are able to make the most of their land area by planting polyculture systems and planting various types of plants.

\section{SUGGESTIONS}

It is recommended that farmers in both regions, highland, and lowland farmers, be given socialization and training about maximum land use so that they can increase knowledge and increase farmer household income.

\section{REFERENCES}

[1]. Anonymous. 2011. Inter and intra-specific competition as an abiotic limiting factor. BPTP. Malang.

[2]. Adi Sarwanto and Widyastuti. 2003. Increasing Corn Production. Penebar Swadaya. Jakarta.86 p.

[3]. Ahmad Rifai, Seno Basuki, Budi Utomo, 2013. Journal of the Value of Equality of Sugar Cane Crops Cultivation with Kedelei: A Case Study in Karangharjo Village, Sulang District, 
Rembang Regency. Institute for Agricultural Technology Studies (BPTP), Central Java.

[4]. Damardjati, D. S., 2007. National Palawija Agribusiness Development Program and Policies. Pp. 51-63. In: Rusastra, I.W., T.A.Napitupulu, M.O. A. Manikmas, F.Kasim (Eds), Palawija Based Agribusiness Development in Indonesia: Its Role in Increasing Food Security and Poverty Alleviation. CAPSA Monograph No. 49, United Nations ESCAP; Food Crop Research and Development Center. Proceedings of the Bogor National Seminar, July 13, 2006.

[5]. Beets, W. C. 1992. Multiple Cropping and Tropical Farming Systems. Gower Publishing Company Limited. England.

[6]. Gomez, A, A, and K, A, Gomez, 1983. Multiple Cropping in The Humid Tropics of Asia. IDRC Ottawa. 248p.

[7]. Ginting, A.N. and H. Yusuf. 1993. Surface Flow and Erosion on Land of Several Plant and Forest Types. Puslithut. Garut.

[8]. Guritno, B. 2011. Cropping Pattern in Dry Land. UB Press, Malang.

[9]. Kidane G.A., Adhonon, N., Legesse D., and Woldeyess. 1990. Cereal/Legume intercropping Research in Ethiopia. In Weddington, R.S., A.F.E. Palmer, and O.T. Edjeeds: Research methods for cereal/Legume intercropping. Proc of a workshop on research methods for cereal/legume intercropping in Eastern and Southern Africa. Mexico, D.F. CIMMYT.

[10]. Kipkemori, P.L. Wasike, V.W., Ooro, P.A., Riungu, T.C., Bor, P.K. and Rogocho, L.M. 1997. Effects of Intercropping Patterns on Soybean and Maize Yield in the Central Rift Valley of Kenya. CYMMYT.

[11]. Lithourgidis AS, Dordas CA, Damalas CA, Vlachostergios DN. 2011. Annual intercrops: an alternative pathway for sustainable agriculture. Aust J Crop Sci 5: 396-410.
[12]. Suwarto, S. Yahya, Handoko, M.A. Chozin. 2005. Corn and Cassava Competition in the Intercropping System. Bul Agron. 33 (2): 1-7.

[13]. Sucipto. 2009. Impact of Row Arrangement of Planting Corn (Zea mays L.) and Population of Green Beans (Phaseolus Radiatus L.) in Intercropping on Growth and Growth of Green Beans, Corn. Agrovigor Vol. 2 (2): 67-78.

[14]. Syaifuddin, I. Mado and Idris. 2010. A difference in the timing of planting green beans in corn planting. Agrosystem Journal. Vol. 6 No. 1. 1-7.

[15]. Sabaruddin L., H. Rachmawati., Muhiddin, and A.A. Anas. 2011. Growth, Production and Land Efficiency in Corn Intercropping Systems and Green Beans with Different Watering Intervals. J. Agron. Indonesia 39 (3): 153 - 159.

[16]. Warsana. 2009. Introduction of Corn and Peanut Intercropping Technology. Agricultural Research Agency. http://www.litbang.deptan.go.id/artikel/one/23 4/ Accessed January 8, 2019.

Cite this article as :

Yusmiati Sabang, Nurariaty Agus, Sitti Bulkis, Muhammad Arsyad, "Land Equation Value of Secondary Plant Polyculture System in High Land and Low Land Farmers", International Journal of Scientific Research in Science and Technology (IJSRST), Online ISSN : 2395-602X, Print ISSN : 2395-6011, Volume 6 Issue 1, pp. 95-99, JanuaryFebruary 2019.

Available at doi :

https://doi.org/10.32628/IJSRST196115

Journal URL : http://ijsrst.com/IJSRST196115 